\title{
The Relationship Between Workload and Burnout Among The Medical Staff In Hospital
}

\author{
Mohd Koharuddin Mohd Balwi *, Dan Wei Yee, Kassim Thukiman, Ana Haziqah \\ School of Human Resource Development and Psychology, Faculty of Social Sciences and Humanities, Universiti Teknologi Malaysia, 81310 UTM Johor \\ Bahru, Johor, Malaysia \\ *Corresponding author: kohar@utm.my
}

Article history: Received: 28 June 2021 Received in revised form: 11 July 2021 Accepted: 25 July 2021 Published online: 05 August 2021

\begin{abstract}
Prolonged occupational stress can lead to the syndrome of job burnout. Workload was one of the factors that can cause the burnout. The main objective of this study was to determine the levels of job burnout and their relationships with workload among the medical staff. The key roles of medical staff in a hospital can be broadly separated into four areas which were the doctors, nurses, allied health professionals and support staff. Eighty medical staff from hospital volunteered to participate in this research. Different data were gathered using the Maslach Burnout Inventory (MBI), NASA-Task Load Index and Demographic questionnaire. The significance of the study was to investigate the relationship between the job burnout and workload among the medical staff in hospitals. The overall level of workload and job burnout was moderate. The results indicated that workload and job burnout among medical staff in hospitals was at moderate level. There was a significant relationship between workload and job burnout in this research.
\end{abstract}

Keywords: Workload, Nasa-TLX, Job Burnout, Maslach Burnout Inventory (MBI), Medical Staff

\begin{abstract}
Abstrak
Tekanan pekerjaan yang berpanjangan boleh menyebabkan sindrom kemerosotan bekerja ( job burnout). Beban kerja adalah salah satu faktor yang boleh menyebabkan keletihan dan kemerosotan bekerja. Objektif utama kajian ini adalah untuk mengetahui tahap kemerosotan bekerja dan hubungan mereka dengan beban kerja dalam kalangan kakitangan perubatan. Peranan utama kakitangan perubatan di sebuah hospital dapat dipisahkan secara luas menjadi empat bidang iaitu doktor, jururawat, profesional kesihatan bersekutu dan staf sokongan. Lapan puluh kakitangan perubatan dari hospital secara sukarela mengambil bahagian dalam penyelidikan ini. Data yang berbeza dikumpulkan menggunakan Maslach Burnout Inventory (MBI), NASA-Task Load Index dan soal selidik Demografi. Kepentingan kajian ini adalah untuk mengkaji hubungan antara job burnout dan beban kerja dalam kalangan kakitangan perubatan di hospital. Tahap keseluruhan beban kerja dan kemerosotan pekerjaan adalah sederhana. Hasil kajian menunjukkan bahawa beban kerja dan kemerosotan pekerjaan dalam kalangan kakitangan perubatan di hospital berada pada tahap sederhana. Terdapat hubungan yang signifikan antara beban kerja dan kemerosotan pekerjaan dalam penyelidikan ini.
\end{abstract}

Kata kunci: Beban Kerja, Nasa-TLX, Job Burnout, Maslach Burnout Inventory (MBI), Kakitangan Perubatan

(C) 2021 Penerbit UTM Press. All rights reserved

\subsection{INTRODUCTION}

Marina (2012) described that the workload was starting from the role of overload, for examples, the personal risk was expanded from one thing to multiples tasks, and the risks of over workload will be happened in some low emotional employees, stuck at the work, low teamwork working environment, and not following the company rules also will caused the employees cannot form a team. Burnout is the emotional condition where the workers feel fatigue and boredness about their job, individual achievement becomes lower and a tendency to depersonalize others (Talachi \& Gorji, 2013). However, that was easily caused by the job burnout happening in the service industry when compared to the non- service industries.

Furthermore, there were many job burnouts in the field of medical doctors. Referring to the past research that had happened in Malaysia showed that there was a high degree of burnout syndrome occurred between the clinicians (Boo et al., 2018). According to Xiaoming, Ma, Chang and Shieh (2014), job burnout will happen when the workload becomes worse, in the past study had shown that the overload was the job requirements among the medical staff namely working hours was more than the normal working hours. Besides, the nursing professionals also will face the high levels of stress and workload so they will be exposed to the job burnout at the end (Padilha et al, 2017).

Besides, work stress may lead to the decision making becoming more inaccurate when addressing the needs of the patient in an emergency setting (Vivekanandan et al., 2015). According to Gorondutse \& John (2018), the previous research showed that the Private 
Higher Education Institutions (PHEIs) had faced the problem of workload in Malaysia. Heavy workload, career development, working environment, job insecurity and so on will affect the high prevalence rate of occupational stress in respective industries (Kama et al, 2016). Based on the previous study the workload also happened in public hospital intensive care units among nurses in Malaysia. According to Olds and Clarke (2010) also discovered when the nurse working overtime that may bring some negative effect to the nurse, especially the safety of the patient in the hospital.

This paper was conceptualized to identify the relationship between the workload and burnout among the medical staff in hospitals. Job burnout was one of the main corporate world issues which had happened in this few years (Kasa \& Hassan, 2017). According to Kasa \& Hassan (2017), the issues of job burnout and workload that had been arise so we have to pay attention about these issues.

\section{Research Objectives}

The research objectives are as follows:

i. To identify the workload among medical staff in hospital

ii. To identify the job burnout level among medical staff in hospital.

iii. To examine the relationships between workload and job burnout among medical staff in hospital.

\subsection{LITERATURE REVIEW}

As stated by Wickens, Laux \& Hutchins (2014), multi-tasking always leads to a condition of workload.

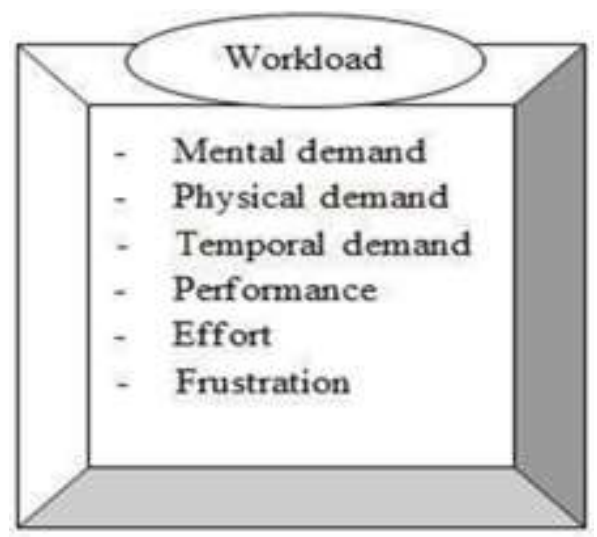

Figure 1 Workload developed by Hart and Staveland, (1988)

For instance, the job diagnosis, low management system, less communication, and other vital task are managed by a worker at the same time. According to Wickens (2013), multi-tasking was defined as the person who can multifaceted, it means the person had to handle current task performance, but also always forcing some task operations. According to Olds and Clarke (2010) also discovered when the nurse working overtime that may bring some negative effect to the nurse, especially the safety of the patient in the hospital. Besides, nurses also may not have enough time to accomplish their task well if they are always working in a high pressure workplace, it also may bring some harm to the patient (Papastavrou, Andreou, \& Efstathiou, 2014). According to Cooley et al. (2015), when the workload among nurses increases then the dangerous situation will also directly bring to the patients.

Workload was the job that had been assigned by the organization to the workers in order to accomplish their task by using their skills and the potential of the workforce (Munandar, 2011). So, it also will cause the employee to feel pressure in their workplace. There were several ways that we can know the worker"s stress which was that we can reflect from the workplace. Workload was defined as a subjective way due to the workload perception will vary for every individual (Gorondutse \& John, 2018). According to Hooi \& Ali (2017), bank employees were required to keep the awesome work performance standards, that was because the workplace condition in the banking industry will require full attention and caution to make sure the transaction will not occur any error. So, this will make the employees always feel stress or tension during their working time (Ling, Bahron \& Boroh, 2014).

According to Bennet (2000), an independent variable was the variable that stimulated the results or the outcome of the dependent variable. The workload was the independent variable and job burnout was the dependent variable in this research. According to Nikulin et al. (2019), there were six dimensions that will be shown in overall workload (OW). Figure 1 showed the 6 workload items which used to get the information about the level of workload among the medical staff at hospital.

Job burnout may bring some negative effect to the organization because they will felt fatigue when they over workload in their work position, they also will felt dissatisfaction among their co-worker when they cannot met the expectation with their current job demands, then it will bring the worker toward the emotional exhaustion, depersonalization and personal achievement (Maslach, 2005).

There were some physical and mental problems that will happen when the job pressures become higher and it may lead to job burnout (Gorji, 2011). According to Wu, et al. (2018), job burnout will not only affect the professional "es personal daily life and also may cause their time and cost overruns, this may affect the satisfaction of customers. Lastly, the bad result may occur on the project performance. However Cropanzo et al., (2003) argued that burnout may not necessarily come by the quantity of how many workloads an employee may have but the level of intensity of the workload itself or the complexity weight of the tasks. 
Maslach et al. (2005) in the other hand explained that burnout occurred when an individual suffers a prolonged exposure to stressful stimuli, such as work demands, complexity, with lack of appropriate emotional care given by the employer and taken by the employee which later lead to emotional exhaustion as the emotional gratitude has not appropriate attended (Chernis, 2010).

The feeling of emotional depletion soon rise and later form another symptom of detached feelings towards job and create the sense of depersonalization against the working systems, people involved at the workplace and the organization itself with negative perspective, prejudices, and other unsympathetic outlooks towards the whole organizational structure where eventually leads the employee to experience issues in acquiring certain set of goals to be attained (Maslach et al., 2005). Thus, it will diminished the self-accomplishment at work hence this was the stage where the individual or employee will very soon to experience reduced personal accomplishments, where the sense of interest or sense of enjoyment in completing any task at work will no longer attained, as tasks and duty were performed only by the sake of complementing work demands in an emotionally struggling condition hence producing burnout at work (Maslach et al., 2005).

Therefore, this research was believed that it was important to use the Maslach ${ }^{\text {ee }}$ Model of job studying and understanding job burnout. Figure 2 showed that the 3 components of burnout which were the emotional exhaustion, depersonalization and reduced personal accomplishment as it covered the overall indication about job burnout in the employment context or field.

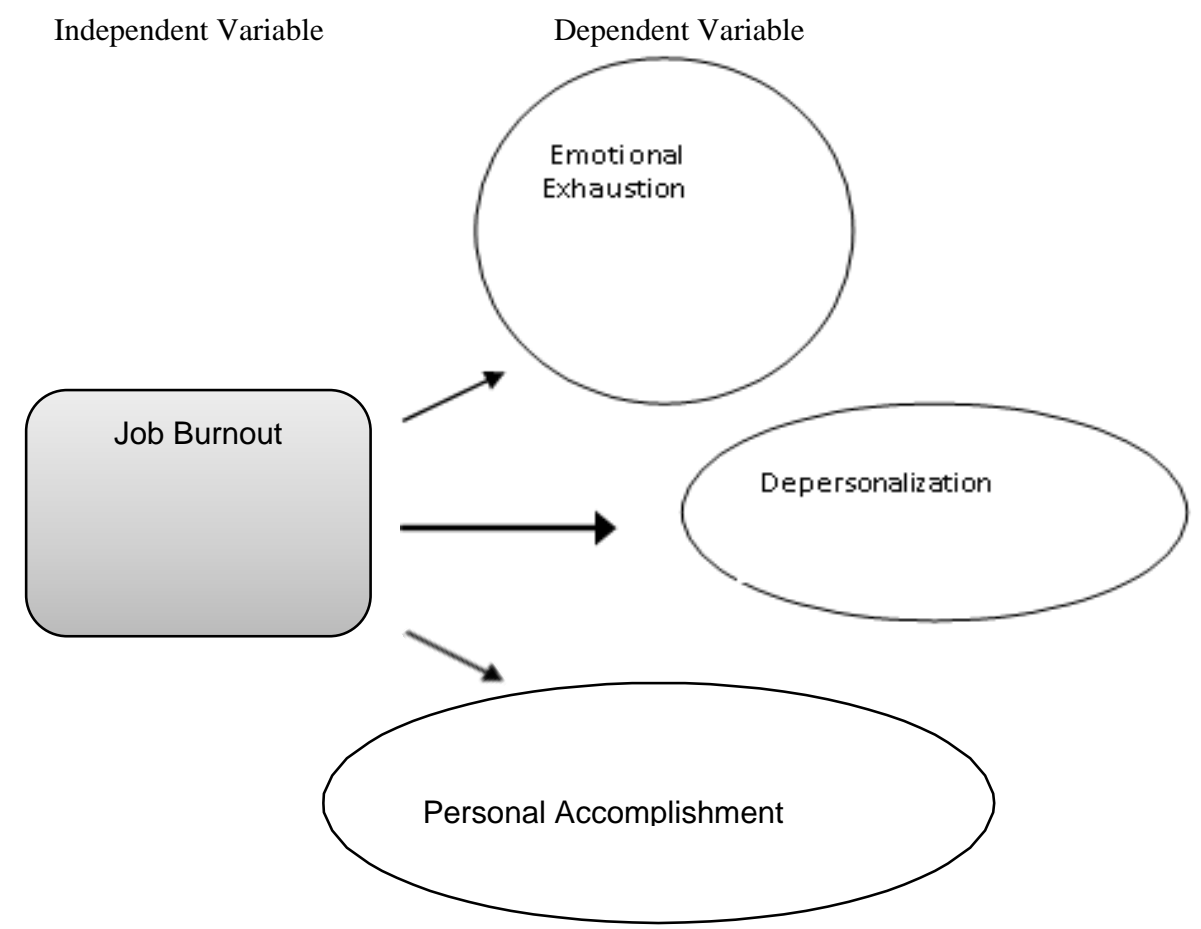

Figure 2 Job Burnout developed by Maslach \& Jackson, (1981)

Relationship between Workload and Job Burnout

Several researches related to establishing the relationship between workload and job burnout had been carried in the past decades. Becker et al. (2005), had laid emphasis on workload at the workplace as one of the most important factors influencing job burnout. Zarei et al. (2019) stated that in the field of physician had caused a heavy workload and will lead the workers towards job burnout when the system of the hospital reformed. According to Wu et al. (2018), job burnout will affect the daily life of a professional and also will lead to time and cost overruns, and will decrease the satisfaction of the recipient, it also will cause job burnout at the end.

According to Hart and Staveland, (1988), the workload can be separated into six dimensions which are the mental demand, physical demand, temporal demand, performance, effort and frustration. Therefore, this research will use the sources of workload which were brought by Hart and Staveland (1988) in establishing the respondent,,s workload.

\subsection{METHODOLOGY}

\section{Research Design}

As stated by Mukherjee (2017), a research design can be used in helping to select the problems that occur in the research like what, when, how much, where and so on that are vital inquiries for a research study. The research design was the understanding of circumstances for collecting in a way that led to separate information that were related to the investigated reason with the economy in the process (Mukherjee, 2017). According to Mukherjee (2017), research design was the theoretical configuration inside which investigation was performed. 
According to Nassaji (2015), the goal of descriptive research was to describe a phenomenon and its characteristics. This research was more concerned with what rather than how or why something had happened (Nassaji, 2015). As stated by Gall, Gall and Borg (2007), observation and survey tools were always utilized to collect data. Besides, in such research, the data can be gathered qualitatively, but it was always analyzed quantitatively by using frequencies, percentages, averages, or other statistical analyses to find out the relationship (Nassaji, 2015). In this study, a quantitative research method was used to gather quantitative data among the respondents. Besides, the descriptive research was designed to identify the level of workload and the level of job burnout.

Meanwhile, a correlational research design examined the relationship between two or more variables within the same group of people (Korb, 2012). In this research, correlational research was designed to examine the strength and direction of correlation between the independent variable (workload) and the dependent variable (job burnout) among the medical staff at hospital.

\section{Population and Sampling}

The population of this research involved all of the medical staff at the hospital. The demographic elements were not limited in the study which included different genders, age, races, academic qualification, marital status, and length of service in the hospital. Therefore, the population of this research involved 100 medical staff at hospital. To determine the 30 sample size of the respondents of the population, researchers used the questionnaire in order to collect data. The sample size was a significant feature of any empirical study in which the goal was to make inferences about a population from a sample (Hamed Taherdoost, 2018).

\section{Measures}

The instrument used in the study was adopted from well-known measurement instruments related to the variable. The questionnaire used to evaluate the level of workload was the NASA-TLX was developed by Hart and Staveland (1988) and the level of job burnout was developed by Maslach (1981). The NASA-TLX was separated into 6 dimensions, namely mental demand, physical demand, temporal demand, frustration, effort and performance. There were 2 dimensions on physical demand, mental demand, temporal demand and performance. The questionnaire consists of 10 items on "Never", "Rarelyee, "Sometimes"e, "Often" or "Always" selections option statements. Besides, Maslach Burnout Inventory (MBI) was separated into 3 dimensions which were emotional exhaustion, depersonalization and personal accomplishment. The questionnaire consists of 22 items in order to measure the level of job burnout among the medical staff.

\section{Data Analysis}

Data collection tools in this study including intrusive tools for example questionnaires. A total of 80 sets of valid questionnaires were collected from the hospital. The Statistical Packages Social Science (SPSS) software version 22 will be used in analyzing the data that was collected from the respondents. In this study, there were two methods of analysis utilized to analyze the data, which were descriptive statistical analysis and inferential statistical analysis.

\subsection{RESULTS}

\section{Demographic Analysis}

Table 1 showed the gender of respondents was unbalanced which consisted of $23.80 \%$ of male and $76.30 \%$ of female. Single and married respondents (50\%) were equally. Respondents in the age group of 26-30 (38.80\%) were the majority and the 46 and above represent the minority (2.50\%). Besides that, 76 respondents had accomplished the high academic qualification which was the diploma and degree and there were 3 respondents who had finished the master degree and only 1 respondent finished in the STPM qualification. Furthermore, the result showed that $73.80 \%$ respondents had worked for less than 6 years in their working position and $26.30 \%$ respondents had more than 6 years in their current position.

Table 1 Demographic Profile of the Respondents

\begin{tabular}{|l|l|l|l|}
\hline \multirow{3}{*}{ Gender } & & Frequency (N) & Percentage (\%) \\
\hline \multirow{3}{*}{ Age } & Male & 19 & 23.80 \\
\cline { 2 - 4 } & Female & 61 & 76.30 \\
\cline { 2 - 4 } & $21-25$ & 11 & 13.80 \\
\cline { 2 - 4 } & $26-30$ & 31 & 38.80 \\
\cline { 2 - 4 } & $31-35$ & 20 & 25.10 \\
\cline { 2 - 4 } & $36-40$ & 8 & 10.10 \\
\cline { 2 - 4 } & $41-45$ & 8 & 10.10 \\
\hline \multirow{6}{*}{ Ethnic } & 46 and above & 41 & 2.50 \\
\cline { 2 - 4 } & Malay & 29 & 51.20 \\
\cline { 2 - 4 } & Chinese & 10 & 36.30 \\
\cline { 2 - 4 } & Indian & & 12.50 \\
\hline
\end{tabular}




\begin{tabular}{|c|c|c|c|}
\hline & Other & - & - \\
\hline \multirow[t]{2}{*}{ Marital Status } & Single & 40 & 50 \\
\hline & Married & 40 & 50 \\
\hline \multirow{6}{*}{$\begin{array}{l}\text { Academic } \\
\text { Qualification }\end{array}$} & PMR & 0 & 0 \\
\hline & SPM & 0 & 0 \\
\hline & STPM & 1 & 1.30 \\
\hline & Diploma & 26 & 32.50 \\
\hline & Degree & 50 & 62.50 \\
\hline & Others & 3 & 3.80 \\
\hline \multirow{4}{*}{$\begin{array}{l}\text { How long you have } \\
\text { been work in this } \\
\text { hospital }\end{array}$} & $1-2$ years & 18 & 22.50 \\
\hline & 3-4 years & 30 & 37.50 \\
\hline & 5-6 years & 11 & 13.80 \\
\hline & 6 years and above & 21 & 26.30 \\
\hline
\end{tabular}

\section{Workload}

Table 2 illustrates the overall mean score of workload of medical staff in hospitals by using the descriptive statistic method. Table 1 illustrates the descriptive statistics on workload among the medical staff in hospital with the moderate mean which was 3.51 . The result showed that it was a moderate mean score on workload. Overall, the majority of the medical staff shows moderate levels of mental demand, physical demand, temporal demand and frustration, high level of performance and effort.

Table 2 Level of Workload

\begin{tabular}{|l|l|l|}
\hline Dimensions & Mean & Level \\
\hline Mental Demand & 3.17 & Moderate \\
\hline Physical Demand & 3.51 & Moderate \\
\hline Temporal Demand & 3.46 & Moderate \\
\hline Performance & 3.74 & High \\
\hline Effort & 3.85 & High \\
\hline Frustration & 3.45 & Moderate \\
\hline Total & 3.51 & Moderate \\
\hline
\end{tabular}

\section{Level of Job Burnout}

The dependent variable of the study was job burnout. The second objective of the study was to determine the level of job burnout. Table 3 showed the overall mean values and standard deviation analysis on job burnout. There was the moderate mean score on job burnout which was 3.18. Overall, the majority of the medical staff showed moderate levels of emotional exhaustion, high levels of depersonalization, and low levels of personal accomplishment.

Table 3 Level of Job Burnout

\begin{tabular}{|l|l|l|}
\hline Dimensions & Mean & Level \\
\hline Emotional Exhaustion & 2.90 & Moderate \\
\hline Depersonalization & 4.06 & High \\
\hline Personal Accomplishment & 2.26 & Moderate \\
\hline Total & 3.18 & Moderate \\
\hline
\end{tabular}

Relationship between Workload and Job Burnout among Medical Staff in Hospital

Table 4 presents the correlations analysis between the workload and job burnout among the medical staff in hospital. The third objective of the study was to determine the relationship between workload and job burnout among medical staff in hospital. Table 3 showed the overall value of correlation coefficient and significant value between workload and job burnout $\left(\mathrm{r}=0.50^{* *}, \mathrm{p}=0.000\right)$. There was the significant medium relationship between workload and job burnout in this study. 
Table 4 Correlations between the Workload and Job Burnout Scores

\begin{tabular}{|l|l|l|l|}
\hline Variables & Emotional Exhaustion & Depersonalization & $\begin{array}{c}\text { Personal } \\
\text { Accomplishment }\end{array}$ \\
\hline Mental Demand & 0.154 & 0.068 & $0.246^{*}$ \\
\hline Physical Demand & $0.261^{*}$ & 0.019 & $0.256^{*}$ \\
\hline Temporal Demand & $0.425^{*}$ & 0.207 & 0.205 \\
\hline Performance & 0.17 & 0.095 & 0.077 \\
\hline Effort & $0.420^{* *}$ & $0.336^{* *}$ & $0.320^{* *}$ \\
\hline Frustration & $0.448^{* *}$ & $0.488^{*}$ \\
\hline Overall mean scores on Workload and Job Burnout $=0.50^{* *}$ \\
\hline \multicolumn{2}{|l}{ *Correlation is significant at the0.05 level(2-tailed), } \\
\hline
\end{tabular}

\title{
5.0 DISCUSSION AND RECOMMENDATION
}

\author{
Discussion on Workload and Job Burnout Level
}

According to Rajan (2018), workload is basically separated into mental and physical workload, in which mental workload mostly happened among managerial cadre employees whereas physical workload happened majorly among operating level employees such as medical staff. This showed that the medical staff had the feelings of workload when they were encountering negative things happened or unexpected situations or their work was overloaded. Workload was a multi-dimensional concept with consideration for time, mental task, physical tasks and stressors (Smith and Smith, 2017). In this study, the findings showed that high and moderate levels happened among the dimensions of workload. There was a moderate level of the workload which was mental demand, physical demand, temporal demand and frustration, performance and effort showed the high level of workload.

Besides, the second objective of the study was to determine the level of job burnout among the medical staff in hospital. Based on the data analysis, the respondents had a high level of depersonalization, moderate level of emotional exhaustion, and low level of personal accomplishment. Furthermore, it also will bring a negative impact to the project performance. Yusoff and Khan (2013) defined that the emotional exhaustion always happened with the physical exhaustion and the symptoms of emotional exhaustion can be included by deficiency of energy, lack of sleep, family conflict and so on. The employee was not suitable to stay in his working position when he was emotionally exhausted.

\section{Discussion on Relationship between Workload and Job Burnout among Medical Staff in Hospital}

The main purpose of this study was to examine the relationship between the independent variable which was the six-dimensions of workload and the dependent variable which was the three-dimensions of job burnout among the medical staff in hospital. Based on the findings had shown that was a medium relationship between the workload and job burnout. Zarei et al. (2019) stated that in the field of physician had caused a heavy workload and will lead the workers towards job burnout when the system of the hospital reformed.

Besides that, regarding Arefi, Ghahramani and Taheri (2010), the previous study revealed that the mental demand will affect the personal accomplishment in their job when the amount of the occupational burnout was low. In this study, the results described that there was no significant relationship between the mental demand and depersonalization among the medical staff. In contrast, according to Khamisa et al. (2015), the poor management system will affect the morale and mental demand of the nurses and it will bring to the feelings of depersonalization. The previous studies also failed to find the relationship that was related between the mental demand and risk of the emotional exhaustion among the health care workers (Van, De, Meijer and Hamers, 2001).

Secondly, this study also determined the relationship between the second dimension of the workload which was physical demand and dimension of job burnout which was emotional exhaustion, depersonalization and personal accomplishment. The previous study stated that the emotional exhaustion will be experienced in the physical demand among the young people (Cheung \& Li, 2019). Moreover, Nurka et al. (2014) stated that the depersonalization as a separate disorder was quite rare. So, there was no significant relationship between physical demand and depersonalization. In addition to, the negative effects of job burnout will exist on physical demand and personal accomplishment, for example, the reduction of quality, efficiency, and the results of their occupations it will bring the job burnout happened (Hedayat et al., 2016).

Thirdly, there was the relationship between the dimension of workload which was temporal demand and dimensions of job burnout. The temporal demand of the workload will affect the emotional of the worker. According to the previous study, emotional exhaustion will be increased among the nurses when there are more patients that have to be handled at the same time (Esther and Ronald \& Kathleen, 2003). The previous study revealed that the limited time in servicing recipients was rarely related to depersonalization (Brotheridge and Grandey, 2002). Regarding the limited previous study there was no mention that the workload perceived by the health worker had related to the personal accomplishment (James, Ninon \& Margaret, 2015).

Fourth, there was the relationship between dimension of workload (performance) and the dimension of job burnout. The present result showed that there was no correlation between the performance and the dimension of job burnout. In contrast, the previous study showed that the burnout was linked to the work performance, high rate of job change and so on (Roghaye et al, 2019). Furthermore, Totawar and Nambudiri (2012) stated that depersonalization was one of the prime components of job burnout and it also can be labelled as an outcome of job stress. From the previous study, the performance of the personnel ${ }^{\text {ee }} \mathrm{s}$ that was clear that there was no correlation between the personal accomplishment and the performance (Gorji, 2011). 
Fifth, there was the relationship between dimension of workload (effort) and the dimension of job burnout. The current result discovered that that was the significant relationship between the effort and the dimensions of job burnout which was the emotional exhaustion, depersonalization and personal accomplishment. From the previous study, when someone who was expressing the unreal emotion will affect the effort in doing their job (Ang, 2010). Erica (2016) stated that the personal accomplishment among the health and well-being of human service workers will have the feelings of ineffectiveness in their working position even though they have put the effort to their job. There was a lack of the past research that related to the relationship between the effort and depersonalization.

Lastly, there was the relationship between dimension of workload (frustration) and the dimension of job burnout. The current result discovered that that was the significant relationship between the frustration and the two dimensions of job burnout which was the emotional exhaustion and depersonalization. The current result showed that there was no correlation among the frustration and personal accomplishment. Regarding the past study, Mansour (2015) defined that the frustration will affect the emotional exhaustion among the nurses that was because nurses always explored the workload.

\section{Limitations and Recommendation}

There were inevitably limitations that cannot be prevented in this study. One of the limitations of this study was the findings of the study cannot be generalized to other populations. It was because the sample size of the study was too small and the research involved only in Johor. Therefore, the results of the research cannot represent other populations such as medical staff in other states.

Besides, another limitation of the study was the number of research about the workload and job burnout was too limited. This was because the topic of the relationship between workload and job burnout was still new among the researchers. The researches of the related topic were only briefly discussed and some of the researchese dimensions of the workload are different from another (Azeem \& Nazir, 2008; P. Balevre, 2001; MacInnes, 2003). However, the results of the research were only applicable to the medical staff those who are working in the hospital. The results of the study might not be applicable to other countries. Last but not least, the study relied on selfreported instruments by using questionnaires for data collection.

In addition, the researcher had given some recommendation to the hospital and future research in order to benefit them from this study. As a continuation of the research findings, recommendations were proposed to the hospital to improve their management system in order to solve the problem of workload and burnout level to be more satisfied. The findings indicated that NASA-TLX and Maslach Burnout Inventory (MBI) were statistically valid and reliable. Therefore, medical staff in hospitals could use these instruments to measure the level of workload and job burnout among the medical staff to measure their physical and mental health in avoiding job burnout existed among the medical staff.

Based on the research limitations, recommendations are also proposed to future research, especially for the topic of workload and job burnout as this topic was not common in Malaysia. This research was targeted on small samples of medical staff in hospital, in which the size of respondents was limited. Therefore, the findings of the research were uncertain to represent the general population of the hospital. In future research, the researcher recommended that the future researchers should increase the number of participants by increasing the number of hospitals involved. As a result, the research will be more accurate with less error obtained.

Besides, this present study only explored the relationship between overall workload and job burnout. Therefore, it was recommended for future research to explore the impact for each dimension of workload and job burnout when studying the relationship especially dimensions in NASA- TLX and MBI so that the research in this scope can be increased. Furthermore, the data collection method employed in this study was a quantitative method whereby the data was obtained according to respondent"s response by using a questionnaire. Distraction factors such as degree of understanding of respondents, environment factors, and personal factors (emotion, time) might result in bias during the process of filling in the questionnaire given. Therefore, a mixed method of qualitative and quantitative approaches was recommended for future research in order to increase the reliability of the result.

\subsection{CONCLUSION}

The findings of the study showed that medical staff had a moderate level of workload, moderate level of emotional exhaustion, high level of depersonalization, and low level of personal accomplishment. In this study that showed the significant medium relationship between the workload and job burnout. All the findings had been discussed, recommendation for hospital and future research had been suggested in order to improve the findings of future study. More research regarding the topic workload and job burnout should be discussed in the future in order to provide public awareness regarding the job burnout level of new generations

\section{References}

American Thoracic Society. Am J Respir Crit Care Med. Vol. 194, P1-P2, 2016. Retrieved from: https://www.thoracic.org/patients/patientsresources/resources/burnout-syndrome.pdf Access on 9 April 2019

Arefi, M., Ghahramani, M., \& Taheri, M. (2010). Assessment Of Prevalence Burnout Syndrome In Academic Staff And Relationship With Demographic Characteristics. Research and Consultancy (News and Research Consultancy), 9(36), 93-110.

Banerjee, A., \& Chaudhury, S. (2010). Statistics Without Tears: Populations And Samples. Industrial Psychiatry Journal, 19(1), 60.

Becker, J. A., Halbesleben, J. R., \& Dan O'Hair, H. (2005). Defensive Communication And Burnout In The Workplace: The Mediating Role Of Leader-Member Exchange. Communication Research Reports, 22(2), 143-150.

Boo, Y. L., Liam, C. C. K., Lim, S. Y., Ling, M., Tan, M. H., Ching, S. M., ... \& Hoo, F. K. (2018). Stress And Burnout Syndrome In Health-Care Providers'. Treating Brotheridge,

C. M., \& Grandey, A. A. (2002). Emotional labor and burnout: Comparing Two Perspectives Of "People Work". Journal Of Vocational Behavior, 60(1), 17-39. Cano-García, F. J., Padilla -Muñoz, E. M., \& Carrasco-Ortiz, M. Á . (2005). Personality And Contextual Variables In Teacher Burnout. Personality And Individual Differences, 38(4), 929-940. 
Chernis, R. E. (2010). The Past In Service Of The Present: A Study Of South African School History Syllabuses And Textbooks 1839-1990 (Doctoral Dissertation, University Of Pretoria).

Cheung, P., \& Li, C. (2019). Physical Activity And Mental Toughness As Antecedents Of Academic Burnout Among School Students: A Latent Profile Approach. International Journal Of Environmental Research And Public Health, 16(11), 2024.

Cropanzano, R., Rupp, D. E., and Byrne, Z. S. (2003). The Relationship Of Emotional Exhaustion To Work Attitudes, Job Performance, And Organizational Citizenship Behaviors. Journal Of Applied Psychology, 88(1), 160-169.

Gall, M. D., Gall, J. P., \& Borg, W. R. (2007). Collecting Research Data With Questionnaires And Interviews. Educational Research: An Introduction, 227-261.

Gorji, M. (2011). The Effect Of Job Burnout Dimension On Employees' Performance. International Journal Of Social Science And Humanity, 1(4), 243.

Hart, S. G., \& Staveland, L. E. (1988). Development Of NASA-TLX (Task Load Index): Results Of Empirical And Theoretical Research. In P. A. Hancock \& N. Meshkati (Eds.), Human Mental Workload, 139-183. Amsterdam: Elsevier

Kama Azida Kamarulzaman, Syazwan Syah Zulkifli, Nor Halim Hasan. (2017). Occupational Stress Among A Cancer Hospital Nurses. Human Factors And Ergonomics Journal. 2(3), 12-20.

Kasa, M., \& Hassan, Z. (2017). The Relationship Of Burnout Dimensions With Organizational Citizenship Behavior (OCB) Among Bank Employees In Sarawak: Mediating Role Of Flow Experience. International Journal Of Business And Society, 18(S4), 685-691.

Khamisa, N., Oldenburg, B., Peltzer, K., \& Ilic, D. (2015). Work Related Stress, Burnout, Job Satisfaction And General Health Of Nurses. International Journal Of Environmental Research And Public Health, 12(1), 652-666.

Korb K. (2012). Conducting Educational Research. Validity Of Instruments.. Http://Korbedpsych.Com/R09evalidity.Html Access on 10 April 2019

Ksenia Zheltoukhova (2012). Taking The Strain: The Impact Of Musculoskeletal Disorders On Work And Home Life. From (Retrieved On 10 December 2012). Access on 10 April 2019

Ling, A. W., Bahron, A., \& Boroch, R. P. (2014). A Study On Role Stress And Job Satisfaction Among Bank Employees In Kota Kinabalu, Sabah. International Journal Of Research In Management \& Business Studies, 1(2), 19-23.

Marina Zambon (2012). Job Factors Related To Musculoskeletal Symptoms Among Nursing Personnel. A Review, 41: 2516-2520.

Maslach, C., Jackson, S. E. (1981). The Measurement Of Experienced Burnout. Journal Of Occupational Behaviour. $2,99-113$.

Munandar, A, S. (2011). Psikologi Industri Dan Organisasi. Jakarta :Universitas Indonesia

Nassaji, H. (2015). Qualitative And Descriptive Research: Data Type Versus Data Analysis.

Olds, D. M., \& Clarke, S. P. (2010). The Effect Of Work Hours On Adverse Events And Errors In Health Care. Journal Of Safety Research, 41(2), 153-162.

Padilha, K. G., Barbosa, R. L., Andolhe, R., Oliveira, E. M. D., Ducci, A. J., Bregalda, R. S., \& Secco, L. M. D. (2017). Nursing Workload, Stress/Burnout, Satisfaction And Incidents In A Trauma Intensive Care Units. Texto \& Contexto- Enfermagem, 26(3), 2-8

Papastavrou, E., Andreou, P., \& Efstathiou, G. (2014). Rationing Of Nursing Care And N urse-Patient Outcomes: A Systematic Review Of Quantitative Studies. The International Journal Of Health Planning And Management, 29(1), 3-25. https://www.scielo.br/j/tce/a/M74Swrx34pHQrbdwjgz4RMc/?lang=pt. Html Access 10 April 2019

Tubbs- Cooley HL, Pickler RH, Younger JB, Mark BA. (2015). A Descriptive Study Of Nurse-Reported Missed Care In Neonatal Intensive Care Units. Journal of Advanced Nursing. 71(4),813-824. Doi:10.1111/Jan.12578

Rajan, D. (2018). Negative Impacts Of Heavy Workload: A Comparative Study Among Sanitary Workers. Sociology International Journal, $2(6), 465-447$.

Smith, A. P., \& Smith, H. N. (2017, June). Workload, Fatigue And Performance In The Rail Industry. In International Symposium On Human Mental Workload: Models And Application, 251-263. Springer, Cham.

Talachi, R. K. \& Gorji, M. B. (2013) „Job Burnout And Job Satisfaction Among Industry, Mine And Trade Organization Employees: A Questionnaire Survey“ International Journal Of Academic Research In Business And Social Sciences, 3(7), Access on 10 April 2019

Totawar, A. K., \& Nambudiri, R. (2012). An Overview Of Depersonalization In The Organizational Context. Indore Management Journal, 4(2), 64-72.

Van Vegchel, N., De Jonge, J., Meijer, T., \& Hamers, J. P. (2001). Different Effort Constructs And Effort-Reward Imbalance: Effects On Employee Well-Being In Ancillary Health Care Workers. Journal Of Advanced Nursing, 34(1), 128-136.

Wickens, C. D., Sebok, A., Hutchins, S. D., Laux, L., Santamaria, A., Clegg, B., Wolfson, N., \& Sargent, R. (2013). Space Performance Research Integration Tool (SPRINT): Development And Validation Of A Model-Based Tool To Predict, Evaluate And Mitigate Excessive Workload Effects. Year 1 Literature Review And Meta-Analyses Summary Report. Submitted To The NASA Human Research Program And The National Space Biomedical Research Institute, Grant No. NNX12AE69G.

Xiaoming, Y., Ma, B. J., Chang, C. L., \& Shieh, C. J. (2014). Effects Of Workload On Burnout And Turnover Intention Of Medical Staff: A Study. Studies On EthnoMedicine, 8(3), 229-237.

Yasmin O. (2011). Autonomous Learning And The Smart School English Language Courseware, Unpublished Dissertation Of Ph.D. Universiti Sains Malaysia. Teacherse Instructional Workload Management And Students"e Academic Performance In Public And Private Secondary Schools In Akoko Northeast Local Government, Ondo State, Nigeria

Yusoff, R. M., \& Khan, F. (2013). Stress And Burnout In The Higher Education Sector In Pakistan: A Systematic Review Of Literature. Research Journal Of Recent Sciences ISSN, (2277), 2502.

Zarei, E., Ahmadi, F., Sial, M. S., Hwang, J., Thu, P. A., \& Usman, S. M. (2019). Prevalence Of Burnout Among Primary Health Care Staff And Its Predictors: A Study In Iran. International Journal Of Environmental Research And Public Health, 16(12), 2249.

Ziaei, M., Yarmohammadi, H., Moradi, M., \& Khandan, M. (2015). Level Of Workload And Its Relationship With Job Burnout Among Administrative Staff. International Journal Of Occupational Hygiene, 7(2), 53-60. 